\title{
Estimation of Tree Species Diversity in Four Campuses of Roever Institutions using Simpsons Diversity Index
}

\author{
Anandan $\mathrm{G}^{1 *}$, Thomas $\mathrm{A}^{2}$, Benickson $\mathrm{C}^{3}$, Chitra $\mathrm{DR}^{3}$, Geethu $\mathbf{M}^{3}$, Augustine $\mathrm{J}^{3}$, Mithun $\mathrm{RM}^{3}$, Shiva $\mathbf{R}^{3}$ and Kavipriya $\mathrm{J}^{3}$ \\ ${ }^{1}$ Department of Forestry, Thanthai Rover Institute of Agriculture and Rural Development, Perambalur, Tamilnadu-621212, India \\ ${ }^{2}$ Department of Horticulture, Thanthai Rover Institute of Agriculture and Rural Development (TRIARD), Perambalur, Tamil nadu-621212, India \\ ${ }^{3}$ Department of Agriculture, Thanthai Rover Institute of Agriculture and Rural Development (TRIARD), Perambalur, Tamilnadu-621212, India
}

\begin{abstract}
Urbanization causes wholesale transformation of the local environment, affecting it at a fundamental level by altering habitat, climate, hydrology, and primary production. Especially tree species richness in an area facilitates the opportunity for the other living organism to develop. Because trees have very long life span, good crown cover to nest, breed and fruits to eat etc. We have studied tree species diversity in four campuses of Roever Educational Institutions. In that we have estimated richness of trees, dominant trees in each campuses, estimated Tree Diversity Index using Simpson's Diversity Index. We found that Thanthai Hans Roever College has highest tree species diversity with the $D$ value of 0.057809222 . Among the all species coconut dominate all the species in richness followed by Drumstick trees.
\end{abstract}

Keywords: Species; Urbanization; transformation; Trees

\section{Introduction}

Species richness has been linked repeatedly with the spatial characteristics of ecosystems. Among the geographic variables used by ecologists Species richness is a fundamental measurement of community and regional diversity, and it underlies many ecological models and conservation strategies. In spite of its importance, ecologists have not always appreciated the effects of abundance and sampling effort on richness measures and comparisons. Quantifying species richness is important, not only for basic comparisons among sites, but also for addressing the saturation of local communities colonized from regional source pools. Maximizing species richness is often an explicit or implicit goal of conservation studies and current and background rates of species extinction are calibrated against patterns of species richness [1]. Therefore, it is important to examine how ecologists have quantified this fundamental measure of biodiversity.

Urbanization causes wholesale transformation of the local environment, affecting it at a fundamental level by altering habitat, climate, hydrology, and primary production. In the case of urban domestic gardens, it is difficult to predict what the relative roles of 'internal' and 'external' factors may be since gardens are managed at an individual level, yet they form interconnected tracts of green space. Especially tree species richness in an area facilitates the opportunity for the other living organism to develop. Because trees have very long life span, good crown cover to nest, breed and fruits to eat etc. comparatively urban trees have very vital role urban biodiversity. The aim of the project is to understand tree species richness in the educational institution. We have studied species richness, given hierarchy of institutions among studied based on the Simpson's species diversity richness formula [2].

\section{Simpson's Species Diversity Index}

Species richness as a measure on its own takes no account of the number of individuals of each species present. It gives equal weight to those species with very few individuals and those with many individuals. A better measure of diversity should take into account the abundance of each species.
Simpson's index (D) is a measure of diversity, which takes into account both species richness, and an evenness of abundance among the species present. In essence it measures the probability that two individuals randomly selected from an area will belong to the same species. The formula for calculating $\mathrm{D}$ is presented as:

$$
\mathrm{D}=\frac{\sum \mathrm{n}_{i}\left(\mathrm{n}_{i}-1\right)}{\mathrm{N}(\mathrm{N}-1)}
$$

Where $\mathrm{n}_{i}=$ the total number of organisms of each individual species $\mathrm{N}=$ the total number of organisms of all species

The value of $\mathbf{D}$ ranges from 0 to 1 . With this index, 0 represents infinite diversity and, 1 , no diversity. That is, the bigger the value the lower the diversity Table 1.

\section{Geography of the Perambalur District}

The district lies in the Southern plateau \& hill zone of Agro-climate regional planning with characteristics of semi-arid climate. The District has an area of 1,756 Sq.Km. (Figure 1) spread between 10.54' and 11.30' degree Northern latitude and 78.40' and 79.30' degree of the Eastern longitude.The soil is predominantly red loamy and black soil. The normal rainfall of the district is $908 \mathrm{~mm}$ which is less than $946.9 \mathrm{~mm}$, the normal rainfall of the State. The precipitation during northeast monsoon, southwest monsoon and remaining winter \& hot weather period account for $52 \%, 34 \%$ and $14 \%$ of annual rainfall, respectively [3].

Cauvery is the major river flowing in the region and the composite district has a canal system covering just $47 \mathrm{~km}$ stretch and ayacut of 11,610 ha. The ground water resource through tube

*Corresponding author: Anandan G, Thanthai Rover Institute of Agriculture and Rural Development, Perambalur, Tamilnadu-621212, India, Tel: 09597149700; E-mail: anandforester@rediffmail.com

Received June 06, 2014; Accepted July 24, 2014; Published July 30, 2014

Citation: Anandan G, Thomas A, Benickson C, Chitra DR, Geethu M, et al. (2014) Estimation of Tree Species Diversity in Four Campuses of Roever Institutions using Simpsons Diversity Index. J Biodivers Endanger Species 2: 135. doi:10.4172/2332-2543.1000135

Copyright: (c) 2014 Anandan G, et al. This is an open-access article distributed under the terms of the Creative Commons Attribution License, which permits unrestricted use, distribution, and reproduction in any medium, provided the original author and source are credited. 
Citation: Anandan G, Thomas A, Benickson C, Chitra DR, Geethu M, et al. (2014) Estimation of Tree Species Diversity in Four Campuses of Roever Institutions using Simpsons Diversity Index. J Biodivers Endanger Species 2: 135. doi:10.4172/2332-2543.1000135

Page 2 of 3

\begin{tabular}{|c|c|}
\hline Low species diversity suggests & High species diversity suggests \\
\hline 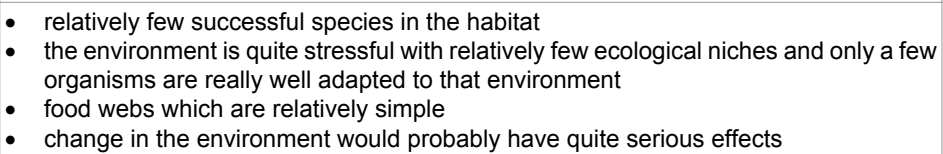 & $\begin{array}{l}\text { - a greater number of successful species and a more stable ecosystemmore } \\
\text { ecological niches are available and the environment is less likely to be hostile } \\
\text { - complex food webs } \\
\text { - environmental change is less likely to be damaging to the ecosystem as a } \\
\text { whole. }\end{array}$ \\
\hline
\end{tabular}

Table 1: The bigger the value the lower the diversity.

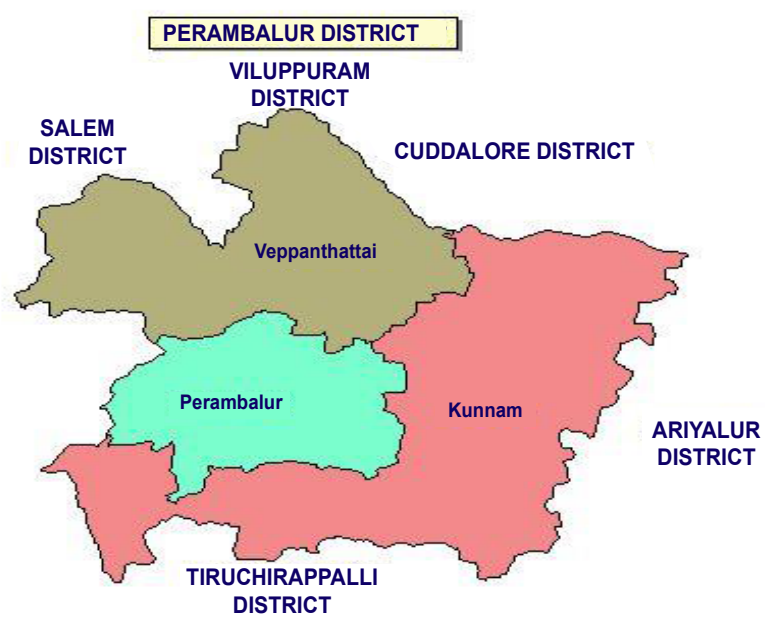

Figure 1: Information about Perambalur district, Tamilnadu, India.

wells and wells contribute nearly $68 \%$ of irrigated area command. The major crops grown in the district are paddy, groundnut, sugarcane and millets. Cashew is the major plantation crop. Now the major cultivation is small Onion, totally $24 \%$ in Tamil Nadu i.e. first place in Tamilnadu [4]. The Onion cultivation villages are Nakkasalem, Ammapalayam, Siruvayalur, Chettikulam, Kalarampatty, Esanai, Arumpavur. Currently, Perambalur district is the top maize and Onion (small) producer in Tamil Nadu, with $27 \%$ and $50 \%$ of the state's share respectively.

\section{Roever Educational Institutions}

We have conducted a survey on tree species richness survey in four major campuses of Roever Education Institutions. The campuses include Roever Institute's Main Campus, Thanthai Roever Institute of Agriculture and Rural Development (TRIARD), Thanthai Hans Roever College of Arts and Science (THRC), Roever Engineering College (REC).

\section{Study Location No 1: Thanthai Roever Institute of Agriculture and Rural Development (TRIARD)}

Thanthai Roever Institute of Agriculture and Rural Development (TRIARD) (Affiliated to Tamilnadu Agricultural University) located in Perambalur is offering courses in Diploma in Agriculture during the year 1994,later Diploma in Horticulture was started during 2001 and B.SC(Agri) degree course during 2008.Thanthai Roever Institute of Agriculture and Rural Development (TRIARD),Perambalur is situated $7 \mathrm{Km}$ from Perambalur bus stand in NH45(Trichy -Chennai bus route). The college has an area of $51.97 \mathrm{ha}(128.4$ acres) for the practical training of the degree and diploma students and to have crop cafeteria for the benefit of the students to see and know the different crop verities. The Institute has 135 acres of land at a stretch.

\section{Study Location No 2: Roever Engineering College}

Roever Engineering College was established in 2001 with the sole purpose of providing quality technical education at affordable costs. REC is part of the larger Roever educational family with a specific focus on research-oriented education. It even provides guides to undertake $\mathrm{PhD}$ program under Anna University Trichirapalli.

\section{Study Location No 3: Thanthai Hans Roever College of Arts and Science}

Thanthai Hans Roever College of Arts and Science, Perambalur, was started in 1985 with 49 students and two disciplines. It is purely a self-financing institution affiliated to the Bharathidasan University and approved by the University Grants Commission, New Delhi. It offers job-oriented graduate courses such as Administration, Mathematics, Physics, Chemistry, Microbiology, Biochemistry, Bio-Technology, Information Technology, Computer Application, Computer Science, Tamil, English, Commerce, Hotel Management, Post graduate courses in Computer Science, Computer Application, Maths, Physics, Chemistry, Commerce, Microbiology, Information Technology, Biochemistry, Bio-Technology, Bio-informatics, Social work, PG Diploma in Bio-informatics, PG Diploma in Actuarial Science and Research Courses M.Phil., (Commerce, Microbiology, Computer Science, Bio-Technology, Tamil, Physics and Chemistry)

\section{Study Location No 4: Roever Educational Institutions main campus.}

The main campus comprises various colleges and offices which are all run under St. John Sangam Trust. The main campus consist College of Physiotherapy, college of Nursing, college of Pharmacy, Roever School of Excellence, Rover Matriculation School, Head office, Hostel for Orphanage students.

\section{Methodology}

In the Simpson's Diversity Index quadrats has to be laid or formulated. The size of the quadrate may vary according the project and there is no fixed size. In our study we have considered one campus as one quadrate and counted all the trees which are all present in the campus. We have individually identified and counted all the trees. For this study we have a carried out an initial survey for tree identification and then we have counted the trees. Our team has worked intensively to count the trees. We have divided in to two groups and counted the same campus individually. This arrangement has helped us to overcome the error or mistake at the time of survey [5].

Trees identified are counted individually and all species are counted and number of trees present in each species in each campus are counted and recorded. At the end we have used Microsoft Excel spread sheet to measure the species diversity. All the data are exploited in the spread sheet in which the Simpson's formula has been formulated. For each four campuses the data of each species present are upload and answers have been calculated individually at species wise and campuses wise also.

\section{Result and Discussion}


Citation: Anandan G, Thomas A, Benickson C, Chitra DR, Geethu M, et al. (2014) Estimation of Tree Species Diversity in Four Campuses of Roever Institutions using Simpsons Diversity Index. J Biodivers Endanger Species 2: 135. doi:10.4172/2332-2543.1000135

Page 3 of 3

\section{Tree species vs. Roever campuses}

Based on the survey we have taken it is our privilege to state the tree species richness in our Roever Institutions. Altogether we have 44 tree species available in the campus that varies from horticultural trees such as Fan palm to economically viable forest trees such as Teak. Roever Engineering College (REC) is the first campus to have maximum of 34 trees species in their campus followed by Thanthai Roever Institute of Agriculture and Rural Development (TRAIRD) with 27 trees species. Number of species available in Roever Main Campus (RMC) is 26 and Thanthai Hans Roever college of Arts and Science (THRC) is 21.

\section{Number of Trees in our campuses}

In our four campuses we have more than 4324 numbers of trees. With 2094 trees Roever Engineering College (REC) dominate in the race followed by Thanthai Roever Institute of Agriculture and Rural Development (TRAIRD) with 1137 trees. Thanthai Hans Roever college of Arts and Science (THRC) won third place with 773 trees followed by Roever Main Campus (RMC) with 320 trees.

We have more than 44 tree species is available in our campuses. Coconut is the largest tree population available among all species. Coconut dominates in two campuses. The first and second largest population of 624 coconut trees found in TRIARD and followed by 511 in REC. The Third largest population is Maringa tree with 467 trees in the REC campus.

In total we have 44 species available in the Roever Campuses. The study area is located in the subtropical conditions and the reader may suspect the low in number of species. We would like to make it clear these are the trees that are planted for the ornamental purpose. The management has taken years of effort to maintain the ornamental view using trees and other horticultural crops. So the trees are not only target, but tree are part of the area beautification.

\section{Tree species diversity ladder}

The aim of the study is to identify the campus with rich in tree species diversity. For that purpose we have used Simplson's Diversity formula. We are proud to state that the Thanthai Hans Roever College of Arts and Sciences (THRC) is the first campus to have tree species richness with $\mathrm{D}$ value of 0.057809222 . The total number of trees is 773 and number of species is 21 . It shows that the campus of variety of species and the numbers are more or less equally distributed among the species. There is no dominancy of one or two species in the population. All 21 species are playing vital role and share equal responsibility in the environment. The first three species with occupy the list are Fan Palm (79 nos), Pagoda tree (78 nos) and Neem tree (76).

The second place goes to Roever Main Campus (RMC) with the D value of 0.126312696 . The total numbers of trees are 320 and number of species is 26 . It shows that the campus of variety of species and the numbers are more or less equally distributed among the species. One important information that we should understand that the RMC is the campus with lowest tree population. Here the diversity is not related to the number of individual but it is related to the distribution of species or weightage of distribution. All 26 species are playing vital role and share equal responsibility in the environment. The campus is rich in ornamental Royal Palm (72 no's) which occupy almost $22.5 \%$ of all species followed by Neem (70 nos) occupy almost $21 \%$ of all species [6]. We would like to mention that at the time of establishment of RMC importance has been given to Royal palm which is adding soothing and

\begin{tabular}{|c|c|c|}
\hline Hierarchy & Campus & Simpsons Diversity Index D Value \\
\hline First Place & THRC & 0.057809222 \\
\hline Second Place & RMC & 0.126312696 \\
\hline Third Place & REC & 0.136394522 \\
\hline Fourth Place & TRIARD & 0.31678218 \\
\hline
\end{tabular}

Table 2: $D$ value is between $0-1$. Result nearer to 0 .

decorative value to the institution. Same amount of interest shown in the Neem Tree in RMC.

The third place goes to REC with the D value of 0.136394522 . The total numbers of trees are 2094 and number of species is 34. It is the campus with higher number of trees and higher number of species. But is placed third place in the hierarchy due to dominance of two species. The Coconut dominates ( 511 nos) almost $24.4 \%$ of the total population and followed by Moringa tree (467 nos) with $22.3 \%$ of dominance. Almost $50 \%$ of the population is shared by these two species and remain shared by 32 species. That is why it is placed in the third place. The index considers only the species richness not total numbers.

The final fourth place goes to TRIARD with the $\mathrm{D}$ value of 0.31678218 . The total numbers of trees are 1137 and number of species is 27 [7]. It is the campus with second highest number of trees and second highest number of species. But is placed fourth place in the hierarchy due to dominance of one species. The Coconut dominates (624 nos) almost $54.88 \%$. This scenario is present in only in this campus only. This is the important why TRIARD is in fourth place of diversity index.

Simpson's Diversity Index D value is between $0-1$. Result nearer to 0 shows rich in diversity and result nearer to 1 show poor in diversity Table 2.

\section{Conclusion}

From the project we have understood the tree planting tradition of Roever Institutions. The four campuses are fully occupied by ornamental trees and commercial trees. This is a unique feature of our Roever tradition. The occupancy of individual tree species differs in each campus but each campus has its own tradition of maintaining greenery in and around the campus. In future the Roever Educational Management may plan to plant number of trees species wherever chance are there. Also must take effort to have diversified tree species which will provide peculiar appearance to the institutes.

\section{References}

1. Airola TM, Buchholz K (1984) Species structure and soil characteristics of five urban forest sites along the New Jersey Palisades. Urban Ecol 8: 149- 164.

2. Boecklen WJ, Gotelli NJ (1984) Island biogeographic theory and conservation practice: species-area or specious- area relationships? Biol Cons. 29: 63-80.

3. Chao A (2004) Species richness estimation. In.N Balakrishnan,C.B.Read, and B.Vidakovic, Encyclopedia of statistical Sciences.New York: Wiley. A comprehensive review of the statistical method for estimating richness.

4. Mugurran AE (2004) Measuring Biological Diversity. Oxford: Blackwell Publishing. The standard reference for conceptual and quantitative aspects of diversity measurement.

5. Tramer EJ, Suhrweir DE (1975) Farm woodlots as bio- geographic islands: regulation of tree species richness. Bull Ecol Soc Am 56: 53.

6. Whittaker RH (1977) Evolution of species diversity in land communities. Evol Biol 10: 1-67.

7. Stevens $\mathrm{MHH}$, Carson WP (1999) Plant density determines species richness along an experimental fertility gradient. Ecology 80: 455- 465. 